\title{
Corruption and growth: a complex relationship
}

\author{
Girijashankar Mallik \\ School of Business \\ Western Sydney University, \\ Sydney, Australia \\ and \\ Shrabani Saha* \\ Lincoln Business School, \\ University of Lincoln, \\ Lincoln, United Kingdom
}

\section{Acknowledgement}

The preliminary version of this paper was presented at the $8^{\text {th }}$ Annual Conference on Economic Growth and Development, Indian Statistical Institute, New Delhi, 2012, University of Western Sydney, Australia. The authors would like to thank all participants for their critical comments and suggestions.

*Corresponding author: Lincoln Business School, University of Lincoln, Lincoln, United Kingdom. Tel: +44 1522835547, email: ssaha@lincoln.ac.uk 


\title{
Growth and corruption: a complex relationship
}

\begin{abstract}
Purpose - This paper investigates the growth-corruption relationship in a sample of 146 countries for the period 1984-2009. While negative effects of corruption on growth have drawn economists' interest in recent years, our main contribution is to examine the effects by employing the hierarchical polynomial regression to evaluate the relationship after controlling economic and institutional factors.

Design/methodology/approach - The results are estimated using panel generalised methods of moments.

Findings - The results challenge some of the findings that negative growth-corruption association in the literature, but also provide some new inferences. The findings reflect that corruption is not always growth-inhibitory, for some countries it is growth-enhancing which supports the "greasing-the-wheels" hypothesis.

Originality/value - The paper investigates the growth-corruption relationship using panel generalised methods of moments. Our results suggest that a cubic function best fitted the data. The finding suggests that in the medium corrupt countries corruption stimulates growth by reducing red-tape.
\end{abstract}

Keywords: Corruption, Growth, GMM, Country Study

JEL Classification: K42, O57, O50 


\section{Introduction}

The pervasiveness of persistence corruption has been tormenting for the majority of developing countries (Asongo, 2013; Cameron et al., 2009). However, the theoretical literature provides no clear guidance on corruption-economic growth relationship. On the one hand, it argues that corruption increases economic growth by enabling investors to avoid bureaucratic delay through the use of "speed money" and by encouraging lowly paid government employees to work harder if they could supplement their income by levying bribes (Leff 1964, Huntington 1968, Lui, 1985, De Soto 1989, Egger and Winner 2005). On the other hand, the theoretical literature contends that corruption has a negative effect on economic growth by reducing investment, both in physical and human capital (Mauro 1995, Keefer and Knack 1997, Reinikka and Svensson 2005) and by leading to a misallocation of public expenditures away from growth-enhancing areas (such as education and health) towards areas which are less productivity enhancing, but are more corruption-intensive (such as large and expensive infrastructural projects) (Mauro 1997, Tanzi and Davoodi 1997).

Likewise, the large empirical literature that has studied the relationship between corruption and economic growth also does not provide a clear and unambiguous answer to the question of whether corruption affects growth positively or negatively (see for example, Mauro 1995, Svensson 2005, Méon and Weill 2008, Aidt 2009 and Paul 2010). Whether corruption affects economic growth negatively or positively seems to depend greatly on the country and regional context (Virta 2010). Moreover, with a few exceptions the researchers' have focused mainly on detecting the linear effects of corruption on growth. But it remains unclear whether an increase in corruption consistently decreases/increases corruption across countries based on categorization of corruption levels. While the linear negative relationship between corruption and economic growth has been noted in the literature, however, the degree of the level of corruption impact on growth is not uniform and straight forward. The overall long-term trend of the entire process may resemble the downward slope portrayed by a linear function, but the non-linear function can discriminate the experiences of less/medium corrupt countries from that of the high corrupt countries.

Moreover, the observed cross-country evidence shows a mixed growth-corruption relationship. For example, country like Australia demonstrates a temperate level of economic growth with a low level of corruption. Contrarily, in spite of China's high level of corruption, its economic growth is very high. On the other hand, a country like Kenya experiences both high level of corruption and low level of economic growth. This propels challenges to the claims of a negative/positive linear relationship between economic growth and corruption. 
In that respect, Swaleheen (2011) first finds a second order polynomial relationship between corruption and growth rate of real per capita income and the effect is more growth enhancing at higher levels that challenges Shleifer and Vishny (1993) which argue that corruption is more growth reducing at higher levels because of how corruption is organized. Hence, for further investigation a cubic non-linear framework is estimated in this paper to explore the degree of changes in economic growth due to a change by in perception of corruption. We question whether a growth of real GDP per capita increases or decreases in various level of perception of corruption i.e. at a low, medium and higher level of perception of corruption.

Our purpose is to offer a systematic analysis for observed cross-country differences in growth and corruption in a cubic non-linear framework by employing panel data analysis. The principal part of our analysis draws on data about levels of corruption for over 146 countries for the period 1984-2009 reported by International Country Risk Guide (ICRG). We supplement this with an additional analysis of an alternative dataset of corruption perception index measured by Transparency International (TI) available since 1995. The advanced panel estimation techniques have been utilized after controlling for fixed effects (both country and period) and endogeneity biases (as corruption and investment are endogenously determined in the sense that they are both correlated with exogenous shocks that affect the rate of economic growth) by employing system generalised methods of moments (SGMM), the most advanced, robust and well recognised technique in the literature.

The next section explores the growth-corruption relationship in detail. Section 3 describes the models, data and econometric methodology and section 4 discusses the results. The final section concludes the analysis.

\section{Exploring the growth-corruption relationship}

The prevailing view is that corruption mainly affects investment and economic growth adversely. A payment of a bribe to get an investment license, for example, clearly reduces the incentive to invest (Bardhan, 1997, p. 1327). Corruption, particularly political or "grand" corruption, distorts the decision-making process connected with public investment projects (Tanzi and Davoodi, 1997). Corruption is likely to increase the number of projects undertaken in a country, and to change the design of these projects by enlarging their size and complexity. The net result is an increase in the share of public investment in GDP, a fall in the average productivity of that investment and (because of budgetary constraints) a possible 
reduction in some other categories of public spending, such as operation and maintenance, education and health. As a consequence, the rate of growth of a country decreases.

Murphy et al. (1993) point out that an increasing return in rent-seeking activities lowers the cost of further rent-seeking relative to that of productive investment. When there is slow growth, the returns to productive activity fall relative to those of rent seeking. The ensuing increase in the pace of rent-seeking activities further slows down growth. It is also argued that public rent-seeking attacks innovation, since innovators need government-supplied goods such as permits and licenses more than established producers.

Another growth effect follows from the allocation of talent. Murphy et al. (1991, p. 503) state that "people choose occupations that offer the highest returns on their abilities when they are free to do so". Rosen (1981) claims that the ablest people choose occupations that exhibit increasing returns to their ability since the increasing returns allow "superstars" to earn extraordinary returns on their talents. When talented people become entrepreneurs, they help to improve the technology in the lines of business they pursue, and, as a result, productivity and income grow. In contrast, when they become rent-seekers, most of their private returns come from redistribution of wealth from others and not from wealth creation. As a result, talented people do not improve technological opportunities, and the economy stagnates. Growth can be much lower than possible if rent-seeking sectors offer most able people higher returns than the productive sectors. Bhagwati et al. (1984) also assert that corruption affects the allocation of human capital because it affects the returns on rentseeking vis-a-vis productive activities.

Some of these growth effects have been statistically substantiated from cross-country data by Mauro (1995) and his study finds that there is a negative and significant association between corruption and growth via the effect on investment. Although the magnitude of the effect is considerable however, this study does not provide any robust evidence because the analysis is not adequate for the dynamic perspective. Furthermore, Mauro $(1997,1998)$ find that corruption reduces expenditures on health and education. As the opportunities to extract high rents from public expenditures on education and health are relatively less, corruption distorts public expenditures away from health and education and encourages excessive infrastructure and capital intensive investment. Hence, corruption reduces the productivity of public investment and the country's infrastructure, which, in turn, has a damaging impact on the country's economic growth. Gupta et al. (2001) confirm that corruption is associated with higher military spending as a share of both gross domestic product and total government 
spending, as well as with arms procurement in relation to GDP and total government spending.

Wei (1997) analyses the adverse effects of corruption on foreign direct investment (FDI) and finds that corruption, acting like a tax, reduces foreign direct investment. He concludes that the less predictable the level of corruption, the greater is its impact on FDI, as higher variability discourages foreign direct investment by increasing risk and uncertainty. In another study, Mo (2001) introduces a new perspective on the role of corruption in economic growth and the most important channel through which corruption affects economic growth is political instability. In other words, corruption is most prevalent where other forms of institutional inefficiency, such as bureaucratic red tape and weak legislative and judicial systems are present.

Oppositely, other studies (led by Leff, 1964 and Huntington 1968) claim that bribery and corruption can have positive effects. The efficiency-enhancing strand views corruption as increasing efficiency because corruption 'greases the wheels'. In the context of pervasive and cumbersome regulations in the developing countries, corruption may actually improve efficiency and enhance growth by using speed money. In examining the positive effect of corruption on growth Méon and Sekkat (2005) and Mendez and Sepulveda (2006), incorporate the interaction terms between corruption/quality of government and economic freedom and find that corruption is beneficial to growth only with good governance and in a free country. Moreover, in a country study, Paul (2010) finds a positive association between corruption and growth in Bangladesh after the economy embarked on privatisation by unleashing private investment.

Recently, Swaleheen (2011) tests corruption-growth relationship in a non-linear frame work (second degree polynomial) but the results show that corruption is not growth reducing at all levels and it significantly increases growth even at a higher level of corruption. ${ }^{1}$ In other words, corruption is more growth reducing when incidence of corruption is low than in countries where incidence of corruption is high. More importantly, this finding rejects the Shleifer and Vishny (1993) hypothesis that "corruption sands-in-the-wheel". This result indeed fuels the so-called debate whether corruption is growth-enhancing or growth-reducing following two approaches, corruption as oil and corruption as sand in the machine, respectively.

\footnotetext{
${ }^{1}$ This paper finds that corruption increases growth even in the second degree equation, for details, see Swaleheen (2011), page 35.
} 
By far, most empirical findings favour the negative linear relationship between corruption and growth i.e. corruption reduces growth; however, real life evidence shows some existence of positive corruption-growth relationship. Moreover, there is a rare cross-country study which captures the non-monotonic behaviour of corruption in influencing growth systematically. This paper evaluates the non-monotonicity of corruption-growth relationship at a third degree in a neoclassical growth model after extending the data set and controlling for fixed effects and endogeneity biases by utilising system generalised methods of moments (SGMM). The purpose is to examine the non-linear effects to determine whether results are consistent with the theory.

\section{Models, data and econometric methodology}

The corruption-growth relationship is examined by using a standard model of growth which is structured as follows:

$$
\begin{aligned}
& \text { Rgdppcygr } r_{i t}=\alpha_{0}+\alpha_{1} \text { Rgdppcyg }_{i t-1}+\alpha_{2} \operatorname{CORR}_{i t}+\alpha_{3}(\text { CORR })_{i t}^{2}+\alpha_{4}(\text { CORR })_{i t}^{3}+\beta^{1} X_{i t}^{1}+\beta^{2} X_{i t}^{2} \\
& +\eta_{i}+\varepsilon_{i t}
\end{aligned}
$$

where Rgdppcygr is the growth rate of real GDP per capita and CORR is the incidence of corruption. $X^{1}$ is the vector of variables used by most cross country growth studies which have been able to explain a significant portion of the variation in real GDP per capita growth. They are SEC (secondary school enrollment rate), Popgr (the growth rate of population, Grat (government final consumption expenditure as a share of GDP)) and Irat (investment GDP ratio). $X^{2}$ is the vector of institutional variables that include Open and Democracy (average of political rights and civil liberties). $\alpha_{0}$ is constant, $\beta^{1}$ and $\beta^{2}$ are vectors of coefficients, $\eta$ is unobserved country fixed effects and $\varepsilon$ is error term. Subscripts $i$ is country $t$ is time.

The purpose of including lagged per capita GDP growth rate is to consider the convergence effect highlighted in the neo-classical growth model and it is expected that the sign of the coefficient is negative. The sign and significance of $\alpha_{2}, \alpha_{3}$ and $\alpha_{4}$ are of interest; $C O R R$ coefficients are expected to be negative if corruption deteriorates the overall economic growth at all levels.

Following neo-classical growth theory it is expected that a higher school enrollment and investment ratio to GDP should boost economic growth whereas, population growth and a 
higher value of government final consumption expenditure negatively affect the growth rate of per capita income (Mankiw et al., 1992). Theory suggests that the impact of openness and democracy should have positive impact on growth (Krueger, 1974 and Barro, 1999).

The major obstacles of comparative studies of corruption have been the lack of a general definition of corruption and the absence of objective cross-national data on corrupt behaviour given its illegal and secret nature. The subjective index of corruption is used as a principal measure, source from International Country Risk Guide (ICRG). The ICRG index is constructed by Political Risk Services. ${ }^{2}$ It measures the corruption within the political system that threatens foreign investment by distorting the economic and financial environment and reducing the efficiency of government and business by enabling people to assume positions of power through patronage rather than ability. For simplicity and ease of exposition, the ICRG index has been converted into a scale from 1 (least corrupt) to 10 (most corrupt). We also use Transparency International's Corruption perception index (CPI) for robustness check. The CPI index is a composite index based on individual surveys from different sources. The index is rescaled in the same scale like the ICRG index.

Real GDP per capita growth (Rgdppcygr) is the dependant variable. The real GDP per capita income (Rgdppcy), openness (Open), and population (Pop) data are obtained from Penn World Table. Data on investment (Irat), government final consumption expenditure (Grat) and secondary school enrolment (Sec) are taken from the World Bank's World Development Indicators (WDI) database. The data are based on annual observations however, we use both annual and the series' long run information by taking averages over five year time intervals (five year time intervals: 1984-1988, 1989-1993, and so on). Due to missing data, the total number of countries used in any regression ranges from 128 to 146 for the period 1984-2009.

\subsection{Methodology}

In order to estimate the impact of corruption on growth, our benchmark model (equation 1) is estimated with ordinary list square (OLS), fixed effects and system GMM. Many researchers used OLS and $2 \mathrm{SLS}^{3}$, but there are advantages of GMM over IV and OLS. If

\footnotetext{
${ }^{2}$ The definition of corruption used is the misuse of public office for private enrichment in this study. See the Political Risk Services (PRS), http://www.prsgroup.com/countrydata.aspx. Also, the PRS data set is regarded as a reliable quantitative measure for the cross-national comparisons and it covers a large number of countries and is available since 1984 .

${ }^{3}$ For example, Chervin and Wijnbergen (2010) used OLS and 2SLS while estimating growth equation using aid volatility.
} 
heteroskedasticity is present, the GMM estimator is more efficient than the simple IV estimator. According to Baum et al. (2003), page 11-“-------if heteroskedasticity is not present, the GMM estimator is no worse asymptotically than the IV estimator". OLS estimation pools observations across cross sections and by using all the variation in the data tends to be more efficient than performing individual OLS on repeated cross sections. The pooled OLS, however, fails to account for the potential endogeneity of the right hand side variables. Specifically, it fails to account for potential country specific variations which are unmodelled and unobserved. In general, the variables measured with an error term tend to display a bias toward zero and OLS does not account for standard errors from the first stage estimator (see Arellano et al. 2009). Moreover, GMM addresses potential endogeneity concerns between the set of cross-country regressors and other country specific characteristics. Further, our model consists of more moment conditions than model parameters, and our panel dataset consists of a short time dimension and a larger country dimension $(N=150)^{4}$. Therefore the use of GMM in this paper is appropriate as it addresses potential endogeneity problems of the regressors and incorporates fixed effects. Arellano and Bond (1991) pioneered the difference-GMM estimator while the system-GMM estimator is a product of the work done by Blundell and Bond (1998). Identification in both types of estimators is based on first-differencing and using lagged values of the endogenous variables as instruments. In the difference-GMM estimator (GMM-DIFF), lagged levels are used to instruments for the differenced right hand side variables, while for the system-GMM estimator (GMM-SYS) the estimated system is composed of a difference equation instrumented with lagged levels and additionally a level equation, which is estimated using lagged differences as instruments (Bond et al. 2001; Rajan and Subramanian 2008) ${ }^{5}$.

We test the instrument validity by using Sargen test for over-identifying restrictions. We make sure we check whether deeper lags of the instrumented variables are correlated with deeper lags of the disturbances.

\section{Empirical results}

\footnotetext{
${ }^{4}$ If the time dimension is large, then dynamic panel bias becomes insignificant - in such a case, a fixed estimator is recommended (see Roodman 2006). Further, as the time dimension of the panel increases, the number of instruments in the GMM-SYS and GMM-DIFF tends to explode; additionally, as the cross-sectional dimension increases, the Arellano-Bond autocorrelation test may become unreliable.

${ }^{5}$ We use the xtdpd command in STATA 10 to conduct all GMM regression analyses.
} 
The relationship between growth and corruption is illustrated with a Kernel fitted line in the scatter plots in Figure 1. The curve shows an existence of a non-linear relationship i.e. the curve is clearly increasing in the middle range of corruption and decreasing where corruption is least and most. In other words, it can be seen that initially as corruption increases percapita income growth reduces slightly and as corruption increases further per-capita growth increases and at a later stage when corruption increases above 6.5-7 on corruption scale, percapita growth reduces at a significant rate. The non-linear fitted line suggests that the "sandsthe-wheels" hypothesis exists at the polar ends of corruption whereas, "greases-the-wheels" effect exists at the middle range of corruption. In order to confirm this result the next step begins by estimating equation (1) with OLS for five year average data and the results are reported in Table 1. The corruption coefficients (measured by ICRG index) illustrate a significant negative linear term, positive squared and negative cubed terms indicating that initially, the function first tended downward, then upward then downward again (column (1)). In other words, the results suggest that corruption is growth reducing in the least and the most corrupt countries but it is growth enriching for the medium corrupt countries.

\section{[FIGURE 1 ABOUT HERE]}

The coefficients for control variables show the expected signs. The coefficient of lagged per capita growth is positive but not significant. The coefficients for secondary school enrolment and investment are positive which increase growth. On the other hand, population growth and government final consumption expenditure coefficients are significant and negative in signs. Openness has a positive sign although not significant. The coefficient for democracy is negative (due to the inversion of democracy index and Rgdppcygr) indicating that democracy enhances growth.

\section{[TABLE 1 ABOUT HERE]}

Column (2) shows the results for two-way fixed effects. The coefficients for corruption (linear, squared, and cubed terms) confirm the similar sign and significance level presented in column (1). Except lagged Rgdppcygr, other control variables have the expected sign. Overall, fixed effects results show that the partial effect of corruption on the rate of growth of real per capita GDP is statistically significant. The OLS and fixed effects estimation results using annual data strongly support our results (columns (3) and (4)). The similar 
results are obtained when corruption is measured by the CPI (columns (5)-(8)) although corruption coefficients are not always significant.

Table 2 displays the results for GMM-system estimation. Column (9) shows that the linear coefficient for corruption is negative but not significant. The result suggests that there is not enough evidence that corruption is growth reducing. The quadratic model in column (10) illustrates a positive linear term and a negative quadratic term indicating a non-monotonic growth-corruption relationship although not significant. However, the results for the cubic model (column (11)) show a negative linear, a positive squared and a negative cubed term and all of these terms are highly significant. This result is robust and consistent with the results shown in Table 1. Moreover, the estimation results using annual series as well as CPI index confirm the significant cubic relationship between growth and corruption (columns (12)-(18)). The results indicate that corruption is not always growth deteriorating; it enhances growth for the medium corrupt countries. The model passes the Sargan test in most of the cases with few exceptions. The model also passes the test of absence of AR (2) in the error term in all cases which reveals the absence of second order serial autocorrelation. With robust estimation investment ratio to GDP is positive and statistically significant. The linear, squared and cubed coefficients of corruption continue to be statistically significant.

\section{[TABLE 2 ABOUT HERE]}

The next step estimates the turning points of the cubic model. The relationship between growth and corruption begins with a negative relationship (see Figure 1) until growth reaches its (local) minimum at a corruption score of around 3.5 where it changes the direction (i.e. negative to positive) and then achieves a maximum at around 7.0 and then starts to decrease again. In other words, the growth rate of per capita income decreases with a corruption score less than 3.5, followed by an increase in the growth level with corruption level between 3.5 and 7.0, and finally growth decreases substantially at the corruption scores that are larger than 7.0. The list of least, medium and the most corrupt countries is presented in Table A1. The results reflect that corruption is growth-inhibitory for the least and the most corrupt countries whereas, it is growth-enhancing for the medium corrupt countries.

Finally we estimate the growth-corruption relationship across least corrupt, medium corrupt and the most corrupt countries based on turning points i.e. corruption level below 3.5, between 3.5 to 7.0 and above 7.0. The estimate for the least corrupt countries (Column (19) Table 3) shows that corruption coefficient is negative although not significant illustrating that 
growth level decreases as the level of corruption increases. In contrast, the middle corrupt countries with corruption level between 3.5-7.0 (column (20) Table 3) display a positive and significant corruption coefficient suggesting that corruption enhances economic growth in these medium corrupt countries. But the most corrupt countries demonstrate that corruption is a bad news for them (column (21)). When corruption is measured in terms of CPI provides the similar results and significant at least 10 percent level of significance. Overall, results in Table 3 reveal that corruption is growth-reducing for the least and the most corrupt countries however, corruption is growth-augmenting for the medium corrupt countries.

\section{[TABLE 3 ABOUT HERE]}

Appendix Table 2A summarises the level and growth of corruption and real GDP per capita and the initial real GDP per capita of these three groups of countries. It is seen that for the low-corrupt countries (the corruption level below 3.5) the average corruption growth is the highest and the per-capita RGDP growth is at 1.896 percent with a highest level of initial per-capita RGDP (for example, Australia and Switzerland). On the other hand, per-capita RGDP growth is the highest at 2.224 percent when the corruption level is between 3.5-7.0 (for instance countries like China and India). When the corruption level is above 7.0 the percapita growth reduces to 1.317 percent although the initial level of per-capita RGDP is the lowest. In general, it is likely that the growth may rise at a faster rate if the initial RGDP is lower, but the higher level of corruption (greater than 7.0) may hinder growth in these most corrupt countries such as Kenya and Libya. Hence, the third degree cubic relationship explains the observed growth-corruption relationship more appropriately.

\section{Conclusion}

The negative effects of corruption have drawn economists' interest in recent years. This paper evaluates the relationship between growth and corruption by employing a hierarchical polynomial regression after controlling economic and institutional factors. In other words, it test whether "sand the wheels" hypothesis always apply in growth-corruption relationship. Our results find that there is a cubic relationship between growth and corruption, such that, for the least corrupt countries corruption impedes growth, but at intermediate levels corruption increases growth, and finally, at a higher level it substantially reduces growth. Hence, the 
"sands the wheels" hypothesis applies only in the polar cases; otherwise, corruption "greases the wheels" at the intermediate levels.

Our empirical results confirm this cubic relationship for various estimation methodologies and corruption indices. In all empirical tests the cubic corruption coefficients are found to be significant at least 10 percent level. In the system GMM for ICRG index the corruption coefficients are significant at the 1 percent level. The model passes the Sargan test and the absence of AR (2) process in the error term. In terms of turning point, we found corruption increases growth within the range around 3.5-7. This pattern is consistent with the "grease the wheels" hypothesis that in the medium corrupt countries corruption stimulates growth by reducing red-tape.

The cubic relationship between growth and corruption illustrates that corruption is a major hindrance to growth in particular for the most corrupt countries such as some African countries. Hence controlling for corruption is vital that enhances economic growth for the most corrupt countries. The choice of policies is crucial dynamics for all nations that fight against corruption. Some studies emphasise the role of institutional reforms to fight corruption (see Asongu (2013) and Batuo and Asongu (2015)). On the other hand, Rosenbaum et al. (2013) find that policy-makers seeking to combat corruption may be more prudent to encourage multifaceted top-down reforms through prohibiting the tax deductibility of bribes, increasing the rotation of public officials or increasing custodial sentences.

\section{Reference}

,Aidt, T. S. (2009), “Corruption, institutions, and economic development”, Oxford Review of Economic Policy, Vol. 25, pp. 271-291.

Arellano, C., Bulir, A., Lane, T. and Lipschitz, L. (2009). "The dynamic implications of foreign aid and its variability", Journal of Development Economics, Vol. 88, pp. 87-102.

Arellano, M. and Bond, S. (1991), "Some tests of specification for panel data: Monte Carlo evidence and an application to employment equations", Review of Economic Studies, Vol. 58, pp. 277-297. 
Asongu, S. A. (2013), "Fighting corruption in Africa: do existing corruption-control levels matter?", International Journal of Development Issues, Vol. 12, pp. 36 - 52.

Bardhan, P. (1997), "Corruption and development: a review of issues”, Journal of Economic Literature, Vol. 35, pp. 1320-1346.

Barro, R. J. (1999), “Determinants of democracy”, Journal of Political Economy, Vol.107, pp. S158-S183.

Baum, C. F., Schaffer, M. E. and Stillman, S. (2003), "Instrumental variables and GMM: Estimation and testing", The Stata Journal, Vol. 3, pp. 1-31.

Batuo, M.E. and Asongu, S. A. (2015),"The impact of liberalisation policies on income inequality in African countries", Journal of Economic Studies, Vol. 42, pp. 68 - 100.

Bhagwati, J. N., Brecher, R. A. and Srinivassan, T. N. (1984), "DUP activities and economic theory", European Economic Review, Vol. 24, pp. 291-307.

Blundell, R. and Bond, S. (1998), "Initial conditions and moment restrictions in dynamic panel data models", Journal of Econometrics, Vol. 87, pp. 115-143.

Bond, S. R., Hoeffler, A. and Temple, J. (2001), "GMM estimation of empirical growth models", CEPR Discussion Papers 3048.

Cameron, L.A., Chaudhuri, A., Erkal, N. and Gangadharan, L. (2009), "Propensities to engage in and punish corrupt behaviour: experimental evidence from Australia, India, Indonesia and Singapore”, Journal of Public Economics, Vol. 93, pp. 843-851.

Chervin, M. and Sweder, S. V. (2010), “Economic growth and the volatility of foreign aid", Tinbergen Institute Discussion Paper 10-002/2.

De Soto, H. (1989), The Other Path: The Invisible Revolution in the Third World. Harper and Row, New York.

Egger. P. and Winner, H. (2005), "Evidence on corruption as an incentive for foreign direct investment”, European Journal of Political Economy, Vol. 21 pp. 932-952.

Gupta, S., Mello, L. D. and Sharan, R. (2001), “Corruption and military spending”, European Journal of Political Economy, Vol. 17, pp. 749-777.

Huntington, S. P. (1968), Political Order in Changing Societies. New Haven: Yale University Press.

Keefer, P. and Knack, S. (1997), "Why don't poor countries catch up? A cross-national test of an institutional explanation”, Economic Inquiry, Vol. 35, pp. 590-602.

Krueger, A. O. (1974), "The political economy of the rent-seeking society", American Economic Review, Vol. 64, pp. 291-303. 
Leff, N. (1964), "Economic development through bureaucratic corruption", American Behavioural Scientist, Vol. 8, pp. 8-14.

Lui, F.T. (1985), “An equilibrium queuing model of bribery”, Journal of Political Economy, Vol. 93, pp. 760-781.

Mankiw, N. G., Romer, D. and Weil, D. N. (1992), "A contribution to the empirics of growth", Quarterly Journal of Economics, Vol. 107, pp. 407-437.

Mauro, P. (1998), "Corruption and the composition of government expenditure", Journal of Public Economics, Vol. 69, pp. 263-279.

Mauro, P. (1997), “Why worry about corruption?”, International Monetary Fund, Economic Issues 6.

Mauro, P. (1995), “Corruption and growth”, Quarterly Journal of Economics, Vol.110, pp. 681-712.

Mendez, F. and Sepulveda, F. (2006), "Corruption, growth and political regimes: cross country evidence", European Journal of Political Economy, Vol. 22, pp. 82-98.

Méon, P. and Sekkat, K. (2005), "Does corruption grease or sand the wheels of growth?", Public Choice, Vol. 122, pp. 69-97.

Méon, P.-G. and Weill, L.(2008), "Is corruption an efficient grease?” BOFIT Discussion Papers, 20.

Mo, P.H. (2001), “Corruption and economic growth", Journal of Comparative Economics, Vol. 29, pp. 66-79.

Murphy, K.M., Shleifer, A. and Vishny, R.W. (1993), "Why is rent-seeking so costly to growth?", American Economic Review, Vol. 83, pp. 409-414.

Murphy, K. M., Shleifer, A. and Vishny, R. W. (1991), “The allocation of talent: implications for growth", Quarterly Journal of Economics, Vol. 106, pp. 503-530.

Paul, B. P. (2010), “Does corruption foster growth in Bangladesh?”, International Journal of Development Issues, Vol. 9, pp. 246-262.

Rajan, R. G. and Subramanian, A. (2008), "Aid and growth: what does the cross-country evidence really show?" The Review of Economics and Statistics, Vol. 90, pp. 643-665.

Reinikka, R. and Svensson, J. (2005), "Fighting corruption to improve schooling: evidence from a newspaper campaign in Uganda", Journal of the European Economic Association, Vol. 3, pp. 259-267.

Roodman, D. (2006), "How to Do xtabond2: An Introduction to "Difference" and "System" GMM in Stata", Center for Global Development Working paper Number 103. 
Rosen, S. (1981), "Economics of superstars”, American Economic Review, Vol. 71, pp. 845858.

Shleifer, A. and Vishny, R.W. (1993), “Corruption”, Quarterly Journal of Economics, Vol. 108, pp. 599-617.

Rosenbaum, S. M., Billinger, S. and Stieglitz, N. (2013),"Private virtues, public vices: social norms and corruption", International Journal of Development Issues, Vol. 12, pp. 192 212.

Svensson, J. (2005), "Eight questions about corruption", Journal of Economics Perspectives, Vol. 19, pp. 19-42.

Swaleheen, M. (2011), "Economic growth with endogenous corruption: an empirical study", Public Choice, Vol. 146, pp. 23-41.

Tanzi, V. and Davoodi, H. (1997), "Corruption, public investment and growth", IMF Working Paper (Vol. 97/139). Washington, D.C.: International Monetary Fund.

Virta, H. (2010), "The linkage between corruption and shadow economy size: does geography matter?", International Journal of Development Issues, Vol. 9, pp. 4 - 24.

Wei, S.-J. (1997), "Why is corruption so much more taxing than tax? Arbitrariness kills", NBER, Cambridge, MA, Working Papers 6255. 
Table 1

The relationship between growth and corruption using OLS and FE

\begin{tabular}{|c|c|c|c|c|c|c|c|c|}
\hline \multicolumn{9}{|c|}{ Dependent variable: RGDPPCYGR } \\
\hline & \multicolumn{4}{|c|}{ Corruption measured by ICRG index } & \multicolumn{4}{|c|}{ Corruption measured by CPI index } \\
\hline & \multicolumn{2}{|c|}{5 year average } & \multicolumn{2}{|c|}{ Annual } & \multicolumn{2}{|c|}{5 year average } & \multicolumn{2}{|c|}{ Annual } \\
\hline & OLS & $\mathrm{FE}$ & OLS & FE & OLS & FE & OLS & FE \\
\hline & $(1)$ & $(2)$ & $(3)$ & $(4)$ & $(5)$ & $(6)$ & $(7)$ & $(8)$ \\
\hline \multirow[t]{2}{*}{ Rgdppcygr(-1) } & 0.0535 & $-0.0745^{*}$ & $0.2209 * * *$ & $0.1349 * * *$ & $0.1360 * * *$ & 0.0572 & $0.2635 * * *$ & $0.1717 * * *$ \\
\hline & $(0.139)$ & $(0.087)$ & $(0.000)$ & $(0.000)$ & $(0.002)$ & $(0.350)$ & $(0.000)$ & $(0.000)$ \\
\hline \multirow[t]{2}{*}{ Corruption } & $-0.0314 * * *$ & $-0.0562 * * *$ & $-0.0152 * * *$ & $-0.0242 * *$ & -0.0128 & $-0.0538 * *$ & -0.0073 & -0.0201 \\
\hline & $(0.000)$ & $(0.000)$ & $(0.003)$ & $(0.011)$ & $(0.146)$ & $(0.043)$ & $(0.180)$ & $(0.138)$ \\
\hline \multirow[t]{2}{*}{ Corruption-SQ } & $0.0080 * * *$ & $0.0124 * * *$ & $0.0040 * * *$ & $0.0056 * * *$ & $0.0035^{*}$ & $0.0135 * * *$ & 0.0017 & $0.0047 *$ \\
\hline & $(0.000)$ & $(0.000)$ & $(0.000)$ & $(0.002)$ & $(0.081)$ & $(0.010)$ & $(0.166)$ & $(0.069)$ \\
\hline \multirow[t]{2}{*}{ corruption-CU } & $-0.0005^{* * *}$ & $-0.0008 * * *$ & $-0.0003 * * *$ & $-0.0004 * * *$ & $-0.0003^{*}$ & $-0.0009 * * *$ & -0.0001 & $-0.0003 * *$ \\
\hline & $(0.000)$ & $(0.000)$ & $(0.000)$ & $(0.001)$ & $(0.060)$ & $(0.003)$ & $(0.147)$ & $(0.034)$ \\
\hline \multirow[t]{2}{*}{ LnSEC } & $0.0048^{*}$ & 0.0135 & 0.0017 & 0.0043 & -0.0027 & $0.0389 * *$ & -0.0017 & 0.0187 \\
\hline & $(0.087)$ & $(0.163)$ & $(0.344)$ & $(0.428)$ & $(0.548)$ & ()0.026 & $(0.637)$ & (0.108) \\
\hline \multirow[t]{2}{*}{ Grat } & $-0.0007 * * *$ & $-0.0019 * * *$ & $-0.0005 * * *$ & $-0.0019 * * *$ & -0.0005 & $-0.0027 * *$ & -0.0004 & $-0.0019 * * *$ \\
\hline & $(0.006)$ & $(0.001)$ & $(0.002)$ & $(0.000)$ & $(0.120)$ & $(0.015)$ & $(0.150)$ & $(0.004)$ \\
\hline \multirow[t]{2}{*}{ Open } & 0.0000 & 0.0001 & $0.0000 *$ & 0.0000 & -0.0000 & -0.0000 & 0.0000 & -0.0002 \\
\hline & $(0.397)$ & $(0.372)$ & $(0.083)$ & $(0.737)$ & $(0.986)$ & $(0.806)$ & $(0.853)$ & $(0.112)$ \\
\hline \multirow[t]{2}{*}{ Popgr } & $-0.4736 * * *$ & $-0.7968 * * *$ & $-0.4071 * * *$ & $-0.4019 * * *$ & $-0.8859 * * *$ & 0.7553 & $-0.8248 * * *$ & $-0.9989 * * *$ \\
\hline & $(0.000)$ & $(0.001)$ & $(0.000)$ & $(0.000)$ & $(0.000)$ & $(0.225)$ & $(0.000)$ & $(0.001)$ \\
\hline \multirow[t]{2}{*}{ Irat } & $0.0017 * * *$ & $0.0022 * * *$ & $0.0009 * * *$ & $0.0010 * * *$ & $0.0011 * * *$ & 0.0000 & $0.0011^{* * *}$ & $0.0012 * * *$ \\
\hline & $(0.000)$ & $(0.000)$ & $(0.000)$ & $(0.000)$ & $(0.001)$ & $(0.926)$ & $(0.000)$ & $(0.000)$ \\
\hline \multirow[t]{2}{*}{ Democracy } & -0.0004 & $-0.0054^{*}$ & -0.0159 & -0.0020 & $0.0023 *$ & -0.0005 & $0.0031 * * *$ & -0.0047 \\
\hline & $(0.666)$ & $(0.063)$ & $(0.155)$ & $(0.157)$ & $(0.084)$ & $(0.926)$ & $(0.001)$ & $(0.137)$ \\
\hline$R$-squared & 0.461 & 0.281 & 0.595 & 0.341 & 0.298 & 0.049 & 0.6434 & 0.427 \\
\hline$F$-test & $160.84 * * *$ & $10.08 * * *$ & $387.91 * * *$ & $19.92 * * *$ & $78.79 * * *$ & $3.62 * * *$ & $285.52 * * *$ & $12.13 * * *$ \\
\hline ( $p$-value) & $(0.000)$ & $(0.000)$ & $(0.000)$ & $(0.000)$ & $(0.000)$ & $(0.000)$ & $(0.000)$ & $(0.000)$ \\
\hline $\begin{array}{l}\text { No. Of } \\
\text { countries/observation }\end{array}$ & $134 / 476$ & $134 / 476$ & $133 / 2505$ & $133 / 2505$ & $146 / 311$ & $146 / 311$ & $128 / 1206$ & $128 / 1206$ \\
\hline s & & & & & & & & \\
\hline
\end{tabular}

Notes: i) $p$-values in parentheses are with robust standard errors; ii) $* * *, * *, *$ indicate significance level at the $1 \%, 5 \%$ and $10 \%$, respectively. 
Table 2

The relationship between growth and corruption using system GMM

\begin{tabular}{|c|c|c|c|c|c|c|c|c|c|c|}
\hline \multicolumn{11}{|c|}{ Dependent variable: RGDPPCYGR } \\
\hline & \multicolumn{6}{|c|}{ Corruption measured by ICRG index } & \multicolumn{4}{|c|}{ Corruption measured by CPI index } \\
\hline & $\begin{array}{c}\text { 5-year } \\
\text { average } \\
(9)\end{array}$ & $\begin{array}{c}\text { 5-year } \\
\text { average } \\
(10)\end{array}$ & $\begin{array}{c}\text { 5-year } \\
\text { average } \\
(11)\end{array}$ & $\begin{array}{c}\text { Annual } \\
\text { (12) }\end{array}$ & $\begin{array}{c}\text { Annual } \\
\text { (13) }\end{array}$ & $\begin{array}{l}\text { Annual } \\
\text { (14) }\end{array}$ & $\begin{array}{c}\text { 5-year } \\
\text { average } \\
(15)\end{array}$ & $\begin{array}{c}\text { Annual } \\
\text { (16) }\end{array}$ & $\begin{array}{c}\text { Annual } \\
\text { (17) }\end{array}$ & $\begin{array}{c}\text { Annual } \\
\text { (18) }\end{array}$ \\
\hline Rgdppcygr(-1) & $\begin{array}{l}-0.0962 \\
(0.252)\end{array}$ & $\begin{array}{c}-0.0989 \\
(0.243)\end{array}$ & $\begin{array}{c}-0.0390 \\
(0.425)\end{array}$ & $\begin{array}{c}0.0965^{* * * *} \\
(0.001)\end{array}$ & $\begin{array}{c}0.0912 * * * \\
(0.001)\end{array}$ & $\begin{array}{c}0.1012 * * * \\
(0.000)\end{array}$ & $\begin{array}{l}0.0020 \\
(0.970)\end{array}$ & $\begin{array}{c}0.1495 * * \\
(0.015)\end{array}$ & $\begin{array}{c}0.1444 * * \\
(0.015)\end{array}$ & $\begin{array}{c}0.1421 * * \\
(0.013)\end{array}$ \\
\hline Corruption & $\begin{array}{c}-0.0009 \\
(0.783)\end{array}$ & $\begin{array}{l}0.0125 \\
(0.352)\end{array}$ & $\begin{array}{c}-0.0309 * * * \\
(0.002)\end{array}$ & $\begin{array}{l}0.0008 \\
(0.639)\end{array}$ & $\begin{array}{l}0.0044 \\
(0.074)\end{array}$ & $\begin{array}{c}-0.0296 * * \\
(0.047)\end{array}$ & $\begin{array}{c}-0.0927 * * \\
(0.039)\end{array}$ & $\begin{array}{l}-0.0019 \\
(0.416)\end{array}$ & $\begin{array}{l}0.0057 \\
(0.325)\end{array}$ & $\begin{array}{c}-0.0205^{*} \\
(0.085)\end{array}$ \\
\hline Corruption-SQ & & $\begin{array}{r}-0.0012 \\
(0.322)\end{array}$ & $\begin{array}{c}0.0079 * * * \\
(0.000)\end{array}$ & & $\begin{array}{c}-0.0003 \\
(0.506)\end{array}$ & $\begin{array}{c}0.0064 * * \\
(0.021)\end{array}$ & $\begin{array}{c}0.0185^{* *} \\
(0.036)\end{array}$ & & $\begin{array}{c}-0.0006 \\
(0.275)\end{array}$ & $\begin{array}{c}0.0050^{*} \\
(0.064)\end{array}$ \\
\hline corruption-CU & & & $\begin{array}{c}-0.0005 * * * \\
(0.000)\end{array}$ & & & $\begin{array}{c}-0.0004 * * \\
(0.015)\end{array}$ & $\begin{array}{c}-0.0011 * * \\
(0.027)\end{array}$ & & & $\begin{array}{c}-0.0003^{*} \\
(0.061)\end{array}$ \\
\hline LnSEC & $\begin{array}{l}0.0137 \\
(0.223)\end{array}$ & $\begin{array}{l}0.0175 \\
(0.170)\end{array}$ & $\begin{array}{l}0.0047 \\
(0.116)\end{array}$ & $\begin{array}{c}0.0208 * * \\
(0.018)\end{array}$ & $\begin{array}{c}0.0216 * * \\
(0.010)\end{array}$ & $\begin{array}{c}0.0169 * * \\
(0.039)\end{array}$ & $\begin{array}{c}0.0732 * * * \\
(0.000)\end{array}$ & $\begin{array}{c}0.0142 * * \\
(0.047)\end{array}$ & $\begin{array}{c}0.0137 * \\
(0.053)\end{array}$ & $\begin{array}{l}0.0112 \\
(0.149)\end{array}$ \\
\hline Grat & $\begin{array}{c}-0.0019 * * \\
(0.048)\end{array}$ & $\begin{array}{c}-0.0018^{*} \\
(0.054)\end{array}$ & $\begin{array}{c}-0.0008^{* * *} \\
(0.011)\end{array}$ & $\begin{array}{c}-0.0005 \\
(0.294)\end{array}$ & $\begin{array}{c}-0.0006 \\
(0.210)\end{array}$ & $\begin{array}{c}-0.0004 \\
(0.380)\end{array}$ & $\begin{array}{c}-0.0016 \\
(0.223)\end{array}$ & $\begin{array}{c}-0.0015^{* * *} \\
(0.018)\end{array}$ & $\begin{array}{c}-0.0015^{* *} \\
(0.021)\end{array}$ & $\begin{array}{c}-0.0016^{* * *} \\
(0.019)\end{array}$ \\
\hline Open & $\begin{array}{l}0.0001 \\
(0.587)\end{array}$ & $\begin{array}{c}-0.0000 \\
(0.928)\end{array}$ & $\begin{array}{c}-0.0001 * \\
(0.069)\end{array}$ & $\begin{array}{l}0.0002 \\
(0.130)\end{array}$ & $\begin{array}{l}0.0001 \\
(0.232)\end{array}$ & $\begin{array}{l}0.0001 \\
(0.150)\end{array}$ & $\begin{array}{c}-0.0001 \\
(0.636)\end{array}$ & $\begin{array}{l}0.0001 \\
(0.182)\end{array}$ & $\begin{array}{l}0.0001 \\
(0.197)\end{array}$ & $\begin{array}{l}0.0002 \\
(0.127)\end{array}$ \\
\hline Popgr & $\begin{array}{c}-0.6252 \\
(0.162)\end{array}$ & $\begin{array}{r}-0.6159 \\
(0.174)\end{array}$ & $\begin{array}{c}-0.5511^{* * *} \\
(0.000)\end{array}$ & $\begin{array}{c}-0.2966 * * * \\
(0.000)\end{array}$ & $\begin{array}{c}-0.3111^{* * *} \\
(0.000)\end{array}$ & $\begin{array}{c}-0.3226 * * * \\
(0.000)\end{array}$ & $\begin{array}{c}-1.8598^{*} \\
(0.089)\end{array}$ & $\begin{array}{c}-1.2615^{* * *} * \\
(0.004)\end{array}$ & $\begin{array}{c}-1.2481 * * * \\
(0.005)\end{array}$ & $\begin{array}{c}-1.2260 * * * \\
(0.005)\end{array}$ \\
\hline Irat & $\begin{array}{c}0.0023 * * * * \\
(0.001)\end{array}$ & $\begin{array}{c}0.0024 * * * \\
(0.000)\end{array}$ & $\begin{array}{c}0.0015 * * * * \\
(0.000)\end{array}$ & $\begin{array}{c}0.0013 * * * \\
(0.000)\end{array}$ & $\begin{array}{c}0.0014 * * * \\
(0.000)\end{array}$ & $\begin{array}{c}0.0014 * * * \\
(0.000)\end{array}$ & $\begin{array}{l}0.0005 \\
(0.503)\end{array}$ & $\begin{array}{c}0.0014 * * * * \\
(0.000)\end{array}$ & $\begin{array}{c}0.0014 * * * * \\
(0.000)\end{array}$ & $\begin{array}{c}0.0013 * * * \\
(0.000)\end{array}$ \\
\hline Democracy & $\begin{array}{c}-0.0148^{* *} \\
(0.019)\end{array}$ & $\begin{array}{c}-0.0159 * * \\
(0.013)\end{array}$ & $\begin{array}{r}-0.0004 \\
(0.768)\end{array}$ & $\begin{array}{r}-0.0042 \\
(0.163)\end{array}$ & $\begin{array}{r}-0.0037 \\
(0.189)\end{array}$ & $\begin{array}{c}-0.0040 \\
(0.130)\end{array}$ & $\begin{array}{l}0.0052 \\
(0.514)\end{array}$ & $\begin{array}{r}-0.0011 \\
(0.728)\end{array}$ & $\begin{array}{r}-0.0009 \\
(0.787)\end{array}$ & $\begin{array}{r}-0.0008 \\
(0.810)\end{array}$ \\
\hline $\begin{array}{l}\text { Maximum } \\
\text { Minimum }\end{array}$ & & & $\begin{array}{l}6.949 \\
2.749\end{array}$ & & & $\begin{array}{l}7.293 \\
3.363\end{array}$ & $\begin{array}{l}7.056 \\
4.013\end{array}$ & & & $\begin{array}{l}6.770 \\
2.919\end{array}$ \\
\hline $\begin{array}{l}\text { Autocorrell (1) } \\
\text { p-values }\end{array}$ & $\begin{array}{l}-2.536 \\
(0.011)\end{array}$ & $\begin{array}{l}-2.553 \\
(0.011)\end{array}$ & $\begin{array}{l}-3.552 \\
(0.000)\end{array}$ & $\begin{array}{l}-18.526 \\
(0.000)\end{array}$ & $\begin{array}{l}-19.164 \\
(0.000)\end{array}$ & $\begin{array}{l}-19.89 \\
(0.000)\end{array}$ & $\begin{array}{l}-3.285 \\
(0.001)\end{array}$ & $\begin{array}{l}-4.9621 \\
(0.000)\end{array}$ & $\begin{array}{l}-5.034 \\
(0.000)\end{array}$ & $\begin{array}{l}-5.034 \\
(0.000)\end{array}$ \\
\hline $\begin{array}{l}\text { Autocorrell (2) } \\
\text { p-values) }\end{array}$ & $\begin{array}{l}-0.696 \\
(0.486)\end{array}$ & $\begin{array}{l}-0.471 \\
(0.638)\end{array}$ & $\begin{array}{l}-0.170 \\
(0.865)\end{array}$ & $\begin{array}{c}0.725 \\
(0.468)\end{array}$ & $\begin{array}{c}0.569 \\
(0.570)\end{array}$ & $\begin{array}{c}0.661 \\
(0.509)\end{array}$ & N/A & $\begin{array}{l}-1.136 \\
(0.256)\end{array}$ & $\begin{array}{l}-1.134 \\
(0.257)\end{array}$ & $\begin{array}{l}-1.1295 \\
(0.259)\end{array}$ \\
\hline $\begin{array}{l}\text { Sargan test-Statistic } \\
\text { (p-value) }\end{array}$ & Robust & Robust & Robust & $\begin{array}{c}1254.964 \\
(0.225)\end{array}$ & $\begin{array}{c}1353.409 \\
(0.364)\end{array}$ & $\begin{array}{c}1395.947 \\
(0.748)\end{array}$ & $\begin{array}{l}31.074 \\
(0.463)\end{array}$ & Robust & Robust & Robust \\
\hline No of Instruments & 72 & 72 & 98 & 122 & 130 & 134 & 112 & 102 & 105 & 122 \\
\hline $\begin{array}{l}\text { No. of } \\
\text { countries/observations }\end{array}$ & $128 / 336$ & $128 / 336$ & $131 / 469$ & $133 / 2308$ & $133 / 2308$ & $133 / 2308$ & $87 / 165$ & $112 / 1069$ & $112 / 1069$ & $112 / 1069$ \\
\hline
\end{tabular}


Note: (i)For 5-year average all the three equations (using ICRG corruption index) are passed the Sargan test-we report p-values corrected using robust standard errors therefore the Sargan test stats are not reported. The results are similar using CPI corruption index, but the Sargan test are not passed therefore are not reported, but the results are available upon request. To do system GMM for any series requires at least three consecutive observations and the corruption data for CPI are not available for longer series especially when averaged for 5-year (Egger and Merlo 2007, pp1538).

ii) $p$ - values in parentheses are with robust standard errors.

iii) $* * *, * * *$ indicate significance level at the $1 \%, 5 \%$ and $10 \%$, respectively. 
Table 3

Growth-corruption relationship in three different groups of countries (using system GMM)

\begin{tabular}{|c|c|c|c|c|c|c|}
\hline \multicolumn{7}{|c|}{ Dependent variable: annual growth rate per capita } \\
\hline & \multicolumn{3}{|c|}{ Corruption measured by ICRG index } & \multicolumn{3}{|c|}{ Corruption measured by CPI index } \\
\hline & $\begin{array}{c}\text { Corrp } \\
(\leq 3.5) \\
(19)\end{array}$ & $\begin{array}{c}\text { Corrp } \\
(3.5 \text { to } 7.0) \\
(20)\end{array}$ & $\begin{array}{c}\text { Corrp } \\
\text { (above 7.0) } \\
(21)\end{array}$ & $\begin{array}{c}\text { Corrp } \\
(\leq 3.5) \\
(22)\end{array}$ & $\begin{array}{c}\text { Corrp } \\
(3.5 \text { to } 7.0) \\
(23)\end{array}$ & $\begin{array}{c}\text { Corrp } \\
\text { (above 7.0) } \\
(24)\end{array}$ \\
\hline Rgdppcygr(-1) & $\begin{array}{r}0.199 * * \\
(0.011)\end{array}$ & $\begin{array}{l}0.0553 \\
(0.943)\end{array}$ & $\begin{array}{l}-0.1129 \\
(0.275)\end{array}$ & $\begin{array}{l}1.3281 * * * \\
(0.000)\end{array}$ & $\begin{array}{l}2.122 * * * \\
(0.000)\end{array}$ & $\begin{array}{l}0.1203 \\
(0.332)\end{array}$ \\
\hline Corruption & $\begin{array}{l}-0.0056 \\
(0.202)\end{array}$ & $\begin{array}{l}0.2405 * * \\
(0.047)\end{array}$ & $\begin{array}{c}-0.0771 * * * \\
(0.004)\end{array}$ & $\begin{array}{l}-0.1050 * * * \\
(0.000)\end{array}$ & $\begin{array}{c}0.1053 * \\
(0.076)\end{array}$ & $\begin{array}{c}-0.0125^{* *} \\
(0.047)\end{array}$ \\
\hline $\begin{array}{l}\text { Wald Chi-square } \\
\text { (p-value) }\end{array}$ & $\begin{array}{c}9.08 \\
(0.011)\end{array}$ & $\begin{array}{c}3.91 \\
(0.141)\end{array}$ & $\begin{array}{c}8.49 \\
(0.014)\end{array}$ & $\begin{array}{c}27.58 \\
(0.000)\end{array}$ & $\begin{array}{c}19.84 \\
(0.000)\end{array}$ & $\begin{array}{c}8.11 \\
(0.017)\end{array}$ \\
\hline $\begin{array}{l}\text { Sargan test-Statistic } \\
\text { (p-value) }\end{array}$ & $\begin{array}{c}260.206 \\
(0.000)\end{array}$ & $\begin{array}{l}12.373 \\
(0.135)\end{array}$ & $\begin{array}{l}76.403 \\
(0.137)\end{array}$ & $\begin{array}{l}17.087 \\
(0.584)\end{array}$ & $\begin{array}{l}10.040 \\
(0.691)\end{array}$ & $\begin{array}{l}59.911 \\
(0.992)\end{array}$ \\
\hline $\begin{array}{l}\text { Autocorrell (1) } \\
\text { (p-value) }\end{array}$ & $\begin{array}{l}-6.096 \\
(0.000)\end{array}$ & $\begin{array}{c}0.076 \\
(0.939)\end{array}$ & $\begin{array}{l}-5.088 \\
(0.000)\end{array}$ & $\begin{array}{l}-4.091 \\
(0.000)\end{array}$ & $\begin{array}{l}-4.046 \\
(0.000)\end{array}$ & $\begin{array}{l}-4.985 \\
(0.000)\end{array}$ \\
\hline $\begin{array}{l}\text { Auto Correlation (2) } \\
\text { (p-value) }\end{array}$ & $\begin{array}{l}1.165 \\
(0.244)\end{array}$ & $\begin{array}{l}-0.097 \\
(0.922)\end{array}$ & $\begin{array}{c}0.273 \\
(0.785)\end{array}$ & $\begin{array}{l}1.278 \\
(0.201)\end{array}$ & $\begin{array}{l}1.345 \\
(0.179)\end{array}$ & $\begin{array}{l}1.086 \\
(0.278)\end{array}$ \\
\hline $\begin{array}{l}\text { No. of } \\
\text { countries/observations }\end{array}$ & $26 / 618$ & $53 / 1163$ & $61 / 476$ & $28 / 379$ & $52 / 522$ & $61 / 476$ \\
\hline
\end{tabular}

Notes: i) $p$-values in parentheses are with robust standard errors.

ii) $* * *, * *, *$ indicate significance level at the $1 \%, 5 \%$ and $10 \%$, respectively. 


\section{Figure 1}

Graph for corruption and per-capita growth:

$(\mathrm{X}$-axis $=$ Corruption and $\mathrm{Y}$-axis $=$ Growth $/$ Capita

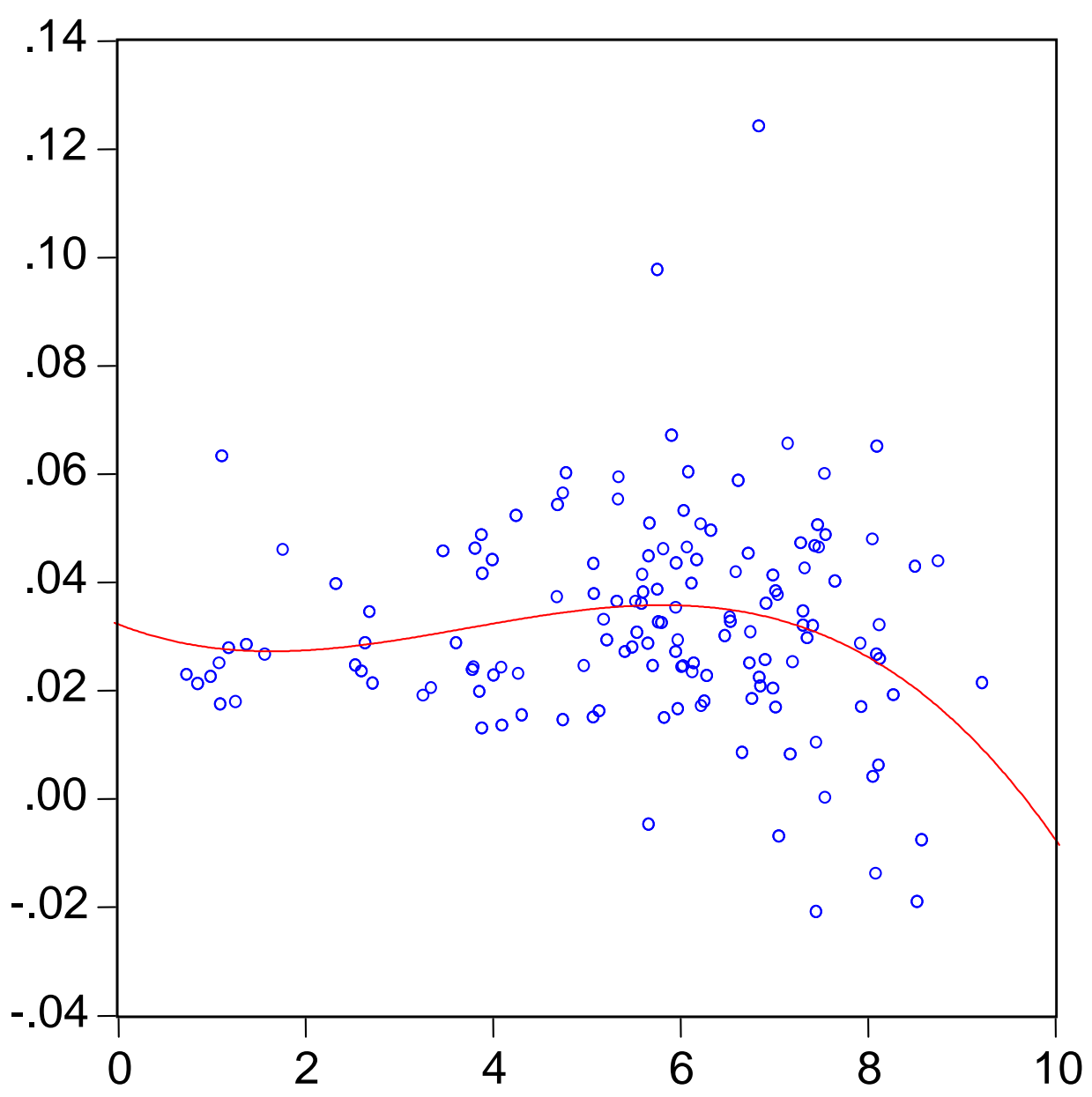




\section{Appendix}

Table A1 Country list for three groups of different level of corruption

\begin{tabular}{|c|c|c|c|c|c|c|c|}
\hline \multicolumn{2}{|c|}{ Below 3.5} & \multicolumn{3}{|c|}{$3.5-7.0$} & \multicolumn{3}{|c|}{ Above 7.0} \\
\hline Australia & Switzerland & Algeria & India & Saudi Arabia & Albania & Iraq & Sierra Leone \\
\hline Austria & $\begin{array}{l}\text { United Arab } \\
\text { Emirates }\end{array}$ & Argentina & Italy & Senegal & Angola & Kazakhstan & Solomon Islands \\
\hline Belgium & United Kingdom & Armenia & Jamaica & Slovak Republic & Bangladesh & Kenya & Sudan \\
\hline Canada & United States & Bahrain & Jordan & Slovenia & Belarus & Kyrgyz Republic & Syria \\
\hline Chile & Uruguay & Botswana & $\begin{array}{l}\text { Korea, Dem. } \\
\text { Rep. }\end{array}$ & South Africa & Bolivia & Libya & Tajikistan \\
\hline Denmark & & Brazil & Kuwait & Sri Lanka & Burundi & Macedonia, FYR & Tanzania \\
\hline Finland & & Brunei Darussalam & Latvia & Taiwan & Cambodia & Mali & Togo \\
\hline France & & Bulgaria & Lesotho & Thailand & Cameroon & Mauritania & Turkmenistan \\
\hline Germany & & Burkina Faso & Lithuania & $\begin{array}{l}\text { Trinidad and } \\
\text { Tobago }\end{array}$ & $\begin{array}{l}\text { Congo, Dem. } \\
\text { Rep. }\end{array}$ & Moldova & Uganda \\
\hline Hong Kong & & China & Madagascar & Tunisia & Congo, Rep. & Mongolia & Ukraine \\
\hline Iceland & & Colombia & Malawi & Turkey & Cote d'Ivoire & Mozambique & Venezuela, RB \\
\hline Ireland & & Costa Rica & Malaysia & & Ecuador & Myanmar & Vietnam \\
\hline Israel & & Croatia & Malta & & $\begin{array}{l}\text { Egypt, Arab } \\
\text { Rep. }\end{array}$ & Nepal & Yemen, Rep. \\
\hline Japan & & Cuba & Mauritius & & Gabon & Nicaragua & Zambia \\
\hline Luxembourg & & Cyprus & Mexico & & Gambia, The & Niger & Zimbabwe \\
\hline Netherlands & & Czech Republic & Morocco & & Georgia & Nigeria & \\
\hline New Zealand & & Dominica & Namibia & & Guinea & Pakistan & \\
\hline Norway & & El Salvador & Oman & & Guinea-Bissau & Papua New Guinea & \\
\hline Portugal & & Estonia & Panama & & Guyana & Paraguay & \\
\hline Qatar & & Ghana & Peru & & Haiti & Philippines & \\
\hline Singapore & & Greece & Poland & & Honduras & Russian Federation & \\
\hline Spain & & Guatemala & Romania & & Indonesia & $\begin{array}{l}\text { Sao Tome and } \\
\text { Principe }\end{array}$ & \\
\hline
\end{tabular}




\begin{tabular}{|l|l|l|l|l|l|l|l|}
\hline Sweden & & Hungary & Rwanda & & Iran & Serbia & \\
\hline
\end{tabular}

Table A2 Summary table-Corruption, corruption growth, per-capita growth, economic growth and Initial per-capita RGDP

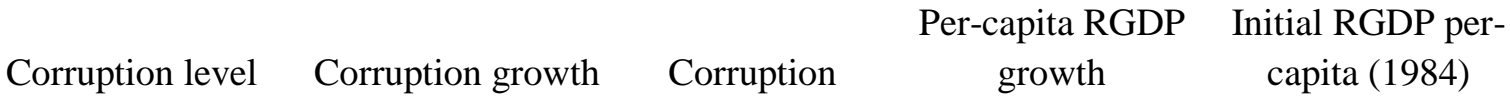

\begin{tabular}{lllll} 
Below 3.5 & 1.2 & 1.969 & 1.896 & 22244.316 \\
$3.5-7.0$ & 0.9 & 5.802 & 2.224 & 8351.448 \\
Above 7.0 & 0.3 & 7.786 & 1.317 & 2866.683 \\
\hline
\end{tabular}

